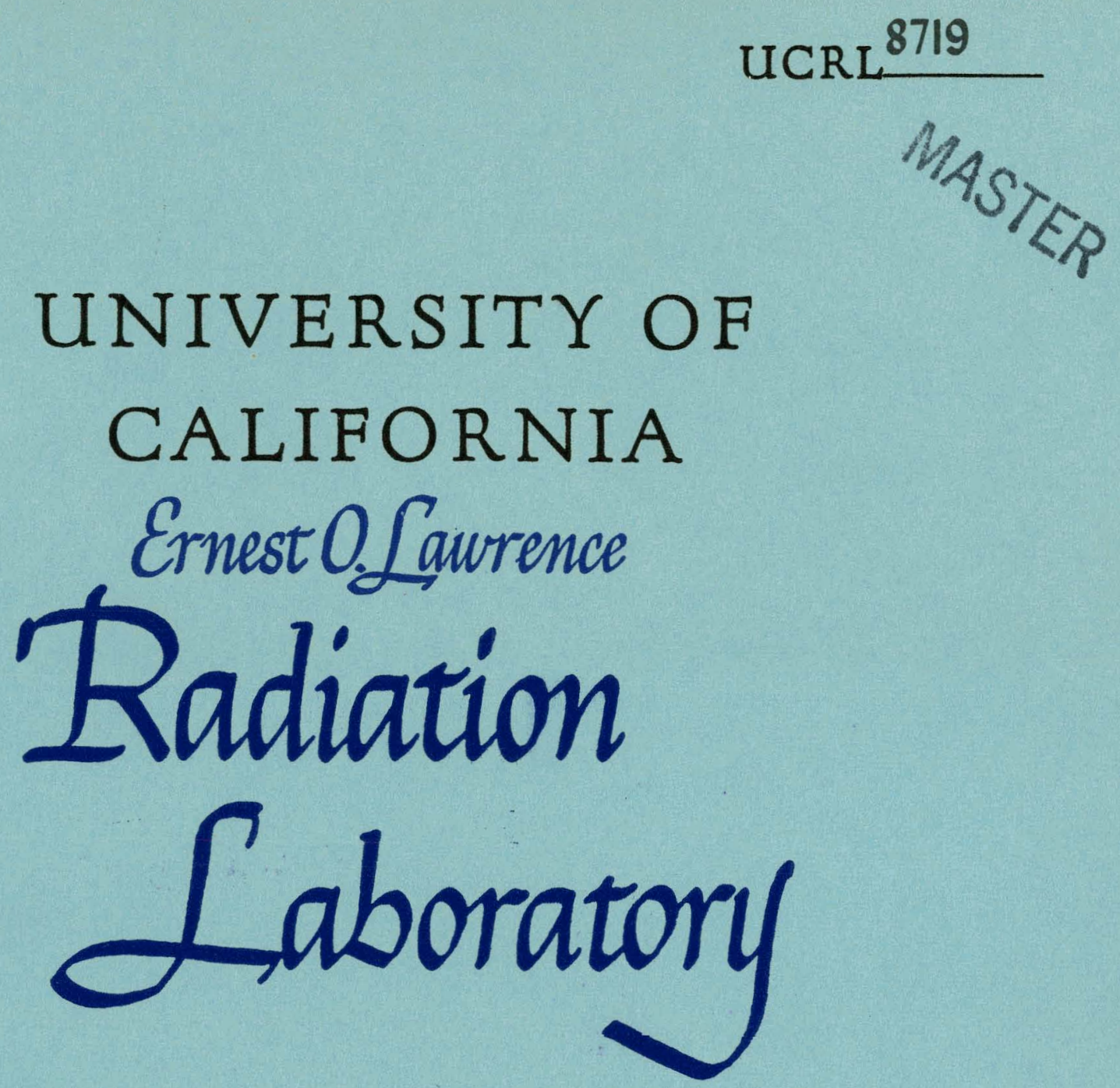

INDIRECT ACTION OF IONIZING RADIATION ON SOME ORGANIC COMPOUNDS CONTAINING THE C-N BOND

BERKELEY, CALIFORNIA 


\section{DISCLAIMER}

This report was prepared as an account of work sponsored by an agency of the United States Government. Neither the United States Government nor any agency Thereof, nor any of their employees, makes any warranty, express or implied, or assumes any legal liability or responsibility for the accuracy, completeness, or usefulness of any information, apparatus, product, or process disclosed, or represents that its use would not infringe privately owned rights. Reference herein to any specific commercial product, process, or service by trade name, trademark, manufacturer, or otherwise does not necessarily constitute or imply its endorsement, recommendation, or favoring by the United States Government or any agency thereof. The views and opinions of authors expressed herein do not necessarily state or reflect those of the United States Government or any agency thereof. 


\section{DISCLAIMER}

Portions of this document may be illegible in electronic image products. Images are produced from the best available original document. 


\section{UNIVERSITY OF CALIFORNIA}

Lawrence Radiation Laboratory

Berkeley, California

Contract No. W-7405-eng-48

\section{INDIRECT ACTION OF IONIZING RADIATION ON SOME ORGANIC} COMPOUNDS CONTAINING THE $C-N$. BOND

Warxen M. Garison

April 1959

Printed for the U. S. Atomic Energy Commission 
UCRL-8719

\title{
INDIRECT ACTION OF IONIZING RADIATION ON SOME ORGANIC COMPOUNDS CONTAINING THE C-N BOND
}

\author{
By Warren M. Garrison \\ Crockor Laboratory and Lawrenco Radiation Laboralory \\ University of California, Berkeley, Caldfornia
}

\section{ABSTRACT}

Observations on the indirect action of ionizing radiation on compounds containing primary amine, secondary amino, $\mathrm{N}$-alkylamide, and peptidebond configurations are correlated in terms of related mechanisms involving the C-N linkage as the locus of chemical change. The radiation chemistry of aqueous solutions of various amino acids and proteins is considered in detail from this viewpoint. Effects of oxygen and other solutes are discussed. Particular reterence is given to: (a) otudies of the radiation-induced oxidation of protein in oxygenated solution, (b) studies of radical-radical. reaction in oxygen-free protein solutions containing a simple $\mathrm{C}^{14}$-labeled organic bolute such as $\mathrm{CH}_{3} \mathrm{C}^{14} \mathrm{OOH}_{\text {. }}$

\section{INTRODUCTION}

Of the various classes of organic compounds contalining the C-N bond, certainly the a-amino acids and derivatives--largely because of their biological import-havo received the greatest attention in radiation chemistry. This paper develope certain opecific aspects of mechanism in the radiolysis of aqueous s.mino acids, both free and combined as native protein. The treatment is based on various literature sources and on information derived from investigations at this laboratory.

The latter have involved (a) detalled radiation chemical studies of particular chemical bonds and groups in the simplex compounda and (b) parallel otudies of corresponding processes as they occur in increasingly complex systems. Ono of the specific objectives of this research has been the dovelopment of oxperimental appioaches that will provide detailed and prociso information on the locl of racliation-induced reaction in protein systorns.

It has often been noted that the radiation chemistry of even the simplex aquo-organic syetems may be complicated conisiderably by the fact that a multiplicity of products can be formed. Further, these products may be encountercd in small arnount and at low concentrations. Fortunately, the 
use of $\mathrm{C}^{14}$-labeled materials in conjuncilon with appropriate radiometric and chromatographic techniques can greatly facilitate the experimental otudy of these systems. In large part, the considerations presented herein have been derived through various applications of such methods.

\section{THE INITIAL REACTION}

Studies of radiation-induced reaction in aqueous solution are generally conoistent with the theory that the earliegt detectable products of water decomposition include $\mathrm{H}$ atoms. $\mathrm{OH}$ radicals, $\mathrm{H}_{2}$, and $\mathrm{H}_{2} \mathrm{O}_{2}$. The initial chemical reaction is conveniently described in terms of the notation 1.2

$$
\mathrm{H}_{2} \mathrm{O} \rightarrow m-\mathrm{H}_{0} \mathrm{OH}_{i} \mathrm{H}_{2}, \mathrm{H}_{2} \mathrm{O}_{2} \text { 。 }
$$

The $100-0 v$ ylelds of the initial products are denoted by $G_{w}(H)_{0} G_{w}(O H)$, $\mathrm{G}_{\mathrm{w}}\left(\mathrm{H}_{2}\right), \mathrm{G}_{\mathrm{w}}\left(\mathrm{H}_{2} \mathrm{O}_{2}\right)$ i the yields of final products are denoted $\mathrm{G}$ (product).

\section{GENERAL ASPFGTS OF INDIRECT ACTION}

The following brief summaxy of the intermediate processes of indirect action will serve to establish the viewpoint of subsequent discusston.

In oxygen-free solutions, the removal of $\mathrm{H}$ and $O H$ in seactions with organic solute may involve simply the hydrogen-abstraction steps

$$
\begin{gathered}
\mathrm{RH}+\mathrm{H} \longrightarrow \mathrm{R}+\mathrm{H}_{2^{\circ}} \\
\mathrm{RH}+\mathrm{OH} \longrightarrow \mathrm{R}+\mathrm{H}_{2} \mathrm{O} .
\end{gathered}
$$

However, whth certain solutes othex (competing) processes oucb as displocement.

$$
\mathrm{ZH}+\mathrm{H} \longrightarrow \mathrm{R}^{\prime} \mathrm{H}+\mathrm{R}^{\prime \prime} \text { 。 }
$$

and addition,

$$
R H+H \longrightarrow R^{\prime}
$$

can be of Importance in the removal of both $H$ and OH. Regardless of other possible intermediate oteps which often complicate the picture, ultimate removal of the organlc freo-radical intermediates involves either disproportionation,

$$
2 R \longrightarrow R H+R^{\prime} H_{0}
$$

and (or) combination.

$$
2 \mathrm{R} \longrightarrow \mathrm{R}-\mathbf{R}_{0}
$$

depending on the nature of the solute. It is to be noted that products of radical combination in some systems may be relatively unimportant in determining over-all product stolchiometry and yet may be of considerable 
interest when considered in relation to the question of reaction mechaniam. Often, information on the nature of the free-radical intermediates can be deduced directly from the chentcal structure of high-molecular-weight products formed in radical-combination processes.

In oxygenated solution, reactions of $\dot{H}$ atoms with solute can be effectively blocked by the competing process

$$
\mathrm{H}+\mathrm{O}_{2} \longrightarrow \mathrm{HO}_{2} \text {. }
$$

whereas reaction between $O H$ and organic solute is unaffected. The chemistry of the oxygenated system, then, is determined primarily by tho properties of intermediates formed via

$$
\mathrm{R}+\mathrm{O}_{2} \longrightarrow \mathrm{RO}_{2}
$$

For certain systems this reaction rnay simply be written

$$
\mathrm{R}+\mathrm{O}_{2} \longrightarrow \mathrm{R} \cdot \mathrm{H}+\mathrm{HO}_{2} \text { 。 }
$$

In such cases the ultimate radical-removal step involves only

$$
2 \mathrm{HO}_{2} \longrightarrow \mathrm{H}_{2} \mathrm{O}_{2}+\mathrm{O}_{2}
$$

Generally, however, removal steps involving both $\mathrm{HO}_{2}$ and $\mathrm{RO}_{2}$ must be involked.

Some opecific applications of the e conslderations to the radiation chernistry of nitrogenous compounds are described in the following sections.

\section{OXYGEN-FREE SOLUTIONS}

The major effects of indirect action on $a$-amino acids of the general type RCH(NH 2 ) COOH result in the formation of $\mathrm{NH}_{3}, \mathrm{RCHOCOOH}_{1} \mathrm{RCH} \mathrm{HOOH}_{2} \mathrm{COO}$ and $\mathrm{H}_{2}$ as princlpal products. Smaller amounts of $\mathrm{RCFO}$ and $\mathrm{CO}_{2}$ havo also

Quantitative data are most complete for the particular case of clycine. Radiolyois studies have been made with $x$-rays, $\gamma$ rays, $\beta$ rays, and cyclotron-produced helium ions. The radiation chemistry of the oxygen-free oolution has been shown 8 to be in accord with the mechaniorn

$$
\begin{aligned}
\mathrm{H}_{2} \mathrm{O} \longrightarrow \mathrm{m} & \mathrm{H}_{1} \mathrm{OH} \mathrm{H}_{2} \mathrm{H}_{2} \mathrm{O}_{2} \\
\mathrm{H}+\mathrm{NH}_{2} \mathrm{CH}_{2} \mathrm{COOH} & \longrightarrow \mathrm{H}_{2}+\mathrm{NH}_{2} \mathrm{CHCOOH} \\
& \longrightarrow \mathrm{NH}_{3}+\mathrm{CH}_{2} \mathrm{COOH}_{2} \\
\mathrm{OH}+\mathrm{NH}_{2} \mathrm{CH}_{2} \mathrm{COOH} & \longrightarrow \mathrm{H}_{2} \mathrm{O}+\mathrm{NH}_{2} \mathrm{CHCOOH}, \\
\mathrm{CH}_{2} \mathrm{COOH}+\mathrm{NH}_{2} \mathrm{CH}_{2} \mathrm{COOH} & \longrightarrow \mathrm{NH}_{2} \mathrm{CHCOOH}+\mathrm{CH}_{3} \mathrm{COOH}, \\
\mathrm{H}_{2} \mathrm{O}_{2}+\mathrm{NH}_{2} \mathrm{CHCOOH} & \longrightarrow \mathrm{H}_{2} \mathrm{O}+\mathrm{OH}+\mathrm{NHCH}_{2} \mathrm{COOH}_{1} \\
& -3-
\end{aligned}
$$




$$
\begin{aligned}
2 \mathrm{NH}_{2} \mathrm{CHCOOH} & \longrightarrow \mathrm{NHCHCOOH}+\mathrm{NH}_{2} \mathrm{CH}_{2} \mathrm{COOH}, \\
\mathrm{H}_{2} \mathrm{O}+\mathrm{NHCHCOOH} & \longrightarrow \mathrm{NH}_{3}+\mathrm{CHOCOOH} .
\end{aligned}
$$

Substantiating evidence for the formation of tho proposed intermediatos $\mathrm{CH}_{2} \mathrm{COOH}$ and $\mathrm{NH}_{2} \mathrm{CHCOOH}$ came from detalled chromatographic studies of the high-molecular-weight product fraction. 8 The entire spectrum of nitrogen-containing products was examined by a procedure which was esBentially a modification of the method of Moore and Stein. 9 The 1rradiated glycine eolution containing $\mathrm{NH}_{2} \mathrm{Cl}^{\mathrm{l}} \mathrm{H}_{2} \mathrm{COOH}$ or $\mathrm{NH}_{2} \mathrm{CH}_{2} \mathrm{Cl}^{14} \mathrm{OOH}$ was added to a Dowex-50 column (hydrogen form) and the radiolysis products plus parcnt glycine were eluted by hydrochloric acid in progrosolvely increasing concentration ( 0 to $4 \mathrm{~N}$ ). Erffluent amples were dried to yield the hydrochlorlde oelto, and product pealk were determined by asaying for C14 activity and (or) by titrating the hydrochloride salt with $0.01 \mathrm{~N}$ sodium hydroxide. Figure 1 shows a typical elution curve for oxygeñ-free $0.25 \mathrm{M}$ glycine solution irradiated with $30-\mathrm{Mov}$ hellum lons. A qualitatively sirnllar curve was obtained with Co 60 y rays. An interesting featuro of these chrornatographs to the relatively largo number of product pealss observed at a radiation dose corresponding to a removal of less than one percent of the paront solute. Two of those activity peake from theix approximate positiono were suspected of being aspartic acid and diaminosuccinic acid respectively. An esiact correopondence between the $\mathrm{C}^{14}$ alabeled proiuct and authentic carrior in titratable amounte was aubsequently observed in both cases. These elution curves are reproduced in Fig. 2. The nonntrogenous organic-acld fraction which pisoed through tho ion-exchange column with littlo or no fractionation or ratention (peak 1. Fig. 1) was subsequenty - eparated by partition chromatography on a allicic acid column through application of methode adopted from the procedure of Marvel and Randc. 10 Activity peaks wero found in the regions correaponding to acetic, glyoxylic, and euccinic acids. Subsequent co-chromatographs of each fraction with the appropriato authentic carrier confirmed these identificetions. The oimplest explanation for the formation of accinic acid, aspartic acid, and diarninoouccinic acid is that small fractions of the $\mathrm{CI}_{2} \mathrm{COO}$ and $\mathrm{NH}_{2} \mathrm{CHCOOH}$ radicals undergo the competing combination reactions

$$
\begin{aligned}
& 2 \mathrm{CH}_{2} \mathrm{COOH} \longrightarrow \text { ouccinic acid, } \\
& \mathrm{NH}_{2} \mathrm{CHCOOH}+\mathrm{CH}_{2} \mathrm{COOH} \longrightarrow \text { aspartic acid, } \\
& 2 \mathrm{NH}_{2} \mathrm{CHCOOH} \longrightarrow \text { diaminosuccinic acid. }
\end{aligned}
$$

It is noted that the formation of succinic acid via dimerization of $\mathrm{CH}_{2} \mathrm{COOH}$ is a principal reaction in the radiolysis of oxygen-firce acetic acid golutions. 11

The above considerations ouggested the possibility that loci involved in the indirect action of radiation on protein molecules could be ascertained through study of radical-radical reactions in protein solvtions ccntaining a second organic solute. For example, in the radiolysis of oxycen-free colutions containing protein molecules RH and a simpler organic solute $R^{\prime} I I$, thero is a given probability of radical combination of the type $R+R^{\prime} \rightarrow R-R^{\prime}$. If the nature of the radical $R^{\prime}$ is known from independent studies, information on the configuration of the protein radical $R$ could be obtained through identification of products formed in conventional hydrolysis 
of the modified proteln $R-R^{\prime}$. It 18 obvlous that the use of $C^{14}$-labeled solutes, $R^{\prime} H$, would greatly facllitate such studles. We have at thls laboratory undertaken studies of the radiation chemisty of a number of protein syotems in which the second solute, $\mathrm{R}^{\prime} \mathrm{H}, \mathrm{I}_{\mathrm{s}} \mathrm{Cl}^{14}$-labeled acetlc acld, (C ${ }^{14} \mathrm{H}_{3} \mathrm{COOH}$ or $\mathrm{CH}_{3} \mathrm{C}{ }^{14} \mathrm{OOH}$ ). Thls solute specles as mentioned earlier ylelds the radical $\mathrm{CH}_{2} \mathrm{COOH}$ on $\mathrm{H}$ and (or) $\mathrm{OH}$ attack. Reactlons of $\mathrm{CH}_{2} \mathrm{COOH}$ with radicals derived from pepein, gelatin, and $\beta$-lactoglobulin have been studied, 12,13

The oxygen-free solutions containing acetic acld and protein at concentrations of $10^{-2} \mathrm{M}$ and $10^{-4} \mathrm{M}$ to $10^{-5} \mathrm{M}$ respectively were irradiated with 40-Mev helium Tona from the Crocker Laboratory cyclotran. Irradiation techniques have been described in earlier publications. If The irradiated solutions were distilled to dryness in vacuo to recover $\mathrm{C}^{14}$. laboled acetlc acid. The residue was redissolvedin $\mathrm{N}$ hydrochloric acid and dialyzed for 3 to 4 houra in cellophane againot running water in the cold. The Cl4 actlvity decreased rapidly to a limiting value which did not change appreclably after about 2 houre. (There was negligiblo retentfon of C 14 activity in duplicate mantpulations of unirradiated proteln $-\mathrm{C}^{1} \mathrm{H}_{3} \mathrm{COOH}$ solutions). The dialyzed material was made $4 \mathrm{~N}$ in hydrochloric acid, 0 vacuated, and hydrolyzed for 24 to 36 hours at $\bar{a}$ tomperature of about $90^{\circ} \mathrm{C}$. The hydrolyzate was taken to drynoss in vacuo and chromatographed on Dowex-50 as de acribed above. Elution curves obtained with gelatin, pepeln, and $\beta$-lactoglobulin aro roproduced in Flgs. 3, 4, 5 respectively. Each chromatograph shows a ceries of distinct $\mathrm{C} 14$-activity peaks. The fraction deolenated peak $A$ in each figuro vas found to co-chromatograph with authentic aopartic acid. A typical curvo is ohown in Fig. 6. An aliquot of fraction $A$ from pepsin was treated with nitrous acid to obtain the corresponding hydroxy acid. The matorial wag then chromatographed on tho ollicic acld column with $35 \%$ butanol $(\mathrm{v} / \mathrm{v})$ in chloroform. Correspondence between Cl4 activity and authentic malic acid titer was observed. The simplest explanation for tho formation of C14-1aboled aspartic acid under the conditions of this otudy $1 \mathrm{~s}$ that $\mathrm{CH}_{2} \mathrm{Cl}^{14} \mathrm{OOH}$ radicals combine with protein radicalo containing the - NHH-CH-CO-configuration. The fact that a series of $C^{14}$-labeled nitrogen-containing froducts $1 \mathrm{~s}$ produced in the radiolyois of protein- $\mathrm{CH}_{3} \mathrm{Cl}^{14} \mathrm{OOH}$ solutions suggeate that tho formation of aspartic acid represents but one path of the general radical-radical reaction which can be written

$$
-\mathrm{NH}-\mathrm{C}(\mathrm{R})-\mathrm{CO}+\mathrm{CHI}_{2} \mathrm{COOH} \rightarrow-\mathrm{NH}-\mathrm{C}(\mathrm{R})-\mathrm{CO}-
$$

where $R$ represents any of the amino acld residues. An extensive study of the relative contributions of theso various posolble protein free radicalo io bcing made. In this regard it is noted that peak $A$, as would be expected, is the major $C^{14}$-labeled product from gelatin, aince this protein contalno a large proportion of glycine realdues. However, the fraction of alanine residues to also relatively high. In attempting to measure the rolative contributions of $-\mathrm{NH}-\mathrm{CH}-\mathrm{CO}-$ and $-\mathrm{NH}-\mathrm{C}\left(\mathrm{CH}_{3}\right)-\mathrm{CO}-$ in the formation of observed products we were surpriaed to find that aspartic acld and methyl aspartic acld are not completoly rejolved on the lon-exchange column, at least undor the conditions employed in this otudy. Analyolo of ouch unresolved aminoacld pairs is now being made after conversion to the corresponding hydroxy aclds by nitrous acid treatment. Partition chromatography on the oiliclc 
acid column 10 to then employed to effect a separation.

\section{OXYGENATED SOLUTIONS}

The indirect action of radiation on amino acide in oxygenated solution can be represented to a first approximation by the net over-all reaction:?

$$
\mathrm{RCH}\left(\mathrm{NH}_{2}\right) \mathrm{COOH}+\mathrm{O}_{2}+\mathrm{H}_{2} \mathrm{O} \rightarrow \mathrm{RCOCOOH}\left(\mathrm{RCHO}+\mathrm{CO}_{2}\right)+\mathrm{NH}_{3}+\mathrm{H}_{2} \mathrm{O}_{2}
$$

The following detailed reaction ocheme ${ }^{8}$ has been derived primarily from studies of oxygenated glycine soluitions:

$$
\begin{aligned}
I I & \cap \cdots I_{2} \cap I I_{1} I I_{2} I I_{2} D_{2^{\circ}} \\
\mathrm{H}+\mathrm{O}_{2} & \rightarrow \mathrm{HO}_{2^{\circ}}
\end{aligned}
$$

$\mathrm{OH}+\mathrm{NH}_{2} \mathrm{CH}_{2} \mathrm{COOH} \longrightarrow \mathrm{NH}_{2} \mathrm{CHCOOH}+\mathrm{H}_{2} \mathrm{O}$

$\mathrm{O}_{2}+\mathrm{NH}_{2} \mathrm{CHCOOH} \longrightarrow \mathrm{NHCHCOOH}+\mathrm{HO}_{2}$

$\mathrm{H}_{2} \mathrm{O}+\mathrm{NHCHCOOH} \longrightarrow \mathrm{NH}_{3}+\mathrm{CHOCOOH}_{3}$

$$
2 \mathrm{HO}_{2} \longrightarrow \mathrm{H}_{2} \mathrm{O}_{2}+\mathrm{O}_{2}
$$

It is noted that reaction of $\mathrm{NH}_{2} \mathrm{CHCOOH}$ with $\mathrm{O}_{2}$ to give the imino intermediate NHICHCOOH merely represent 3 the simplest path for removal of $\mathrm{NH}_{2} \mathrm{CHCOOH}$ radicals consistent with the fact that ammonia and glyoxylic acid are formed in approxinately equal yields in oxygen-eaturated solution. 7 Formation of an unstable perosido intormediate via

$$
\begin{gathered}
\mathrm{O}_{2}+\mathrm{NH}_{2} \mathrm{CHCOOH} \rightarrow \mathrm{NH}_{2} \mathrm{CH}\left(\mathrm{O}_{2}\right) \mathrm{COOH} \\
\mathrm{HO}_{2}+\mathrm{NH}_{2} \mathrm{CH}\left(\mathrm{O}_{2}\right) \mathrm{COOH} \rightarrow \mathrm{NH}_{2} \mathrm{CH}\left(\mathrm{O}_{2} \mathrm{H}\right) \mathrm{COOH}+\mathrm{O}_{2}
\end{gathered}
$$

followed by

$$
\mathrm{H}_{2} \mathrm{O}+\mathrm{NH}_{2} \mathrm{CH}\left(\mathrm{O}_{2} \mathrm{HI} \mathrm{COOH} \longrightarrow \mathrm{NH}_{3}+\mathrm{CHOCOOH}+\mathrm{H}_{2} \mathrm{O}_{2}\right.
$$

would of course lead to the same stolchiometxy.

Cleavage of the $C-N$ bond by the Indirect action of radiation is not confined to the primary amino configuration. Secondary amines, for example, undergo radiation-incluced reaction in oxygenated solution to give primary amino and aldehyde, 14

$$
\mathrm{RNHCH} \mathrm{R}^{\prime}+\mathrm{O}_{2}+\mathrm{H}_{2} \mathrm{O} \longrightarrow \mathrm{RNH}_{2}+\mathrm{R}^{\prime} \mathrm{CHO}+\mathrm{H}_{2} \mathrm{O}_{2}^{\prime}
$$

and one of the reactions involved in the radiolysis of aqueous solutions of protein under appropriate conditions apparentiy leads to cleavage of the peptide chain to form the carbonyl and amide functions: 


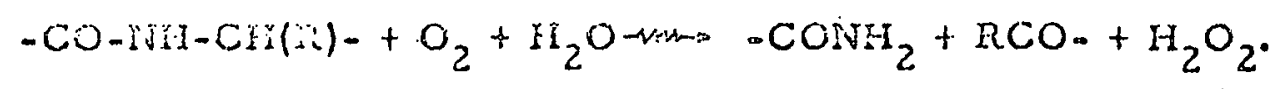

Evidence for the laterer radiation-inclueed oxidation has besn derivod largely from stuli:s of carbonyl prociuction in oxygenated solutions of pepsin aind gclutia. 15, 16 The carbonyl function is found to be associated with highmolecular-weight (nondialyzable) products which on conventional acid hydrolysio yield a series of a-keto acids. Carbonyl compounda in addirton to the eimple o-keto acido are aloo observed.

Bocause of the probable importance of these reactions in radiation biological phenomena, we have undertaken extensive studies of the production of $>C=O$ bonds in the radiolysis of oxygen ated protein oystems.

Irradiations were made with $\mathrm{Co}^{60}$ y rays at a dose rate of $\sim 2 \times 10^{17} \mathrm{ev} / \mathrm{ml} / \mathrm{min}^{2}$. The Eolutions vere exposed under one atmoaphere of oxygen in cealed Fyrex tubes mounted in a motor-driven reel situated at standard distance from the bource.

Immediately after 1 rradiation each of the protein solutions $(5 \mathrm{mg} / \mathrm{m} 1)$ was ireated with platinurn black to destroy hydrogen peroxsido and then treated with 2, 4-dinitrophenylhydrazine ohydrochloric acid solution to form the hydrazone derivatives. (Control runs establiahed that protein oxidation is not induced by the addition of platinum black to these systems.) The solurion vas dialyzed rapidly ia cellophatre against runing vater in the cold to remove excess reagent end possible reaction producte of lovy nolecular - weight. An appropriate aliquet of the dialyzed protein was then added to metherol-potassium inydroxide eolution for spectrophotometric analysis after the nethod of Lappin and Clark. 17 A typical aborption curve (fillod chacles) for in radiated pepsin solution treated in this rnemner 10 shown in Fig. 7. Similar curves wore obtained with gelatin. The absorpition spectrum of a representacivo monocarbosyl derivative (acetaldeliyde 2.4 -elinitrophenylhydrazone) is shown for purposes of comparieon. The upper curve (open circles) shows the absorption spectrum of 2., 4-dinitrophenylhydrazine zaagent under identical conditions. The absorption curve of iradiated pepein treated vith 2 , 4 -dinditrophenylhydrazine is seen to be cheracterietic of the $>\mathrm{C}=\mathrm{N} J-\mathrm{MI}-\mathrm{C}_{6} \mathrm{H}_{4}\left(\mathrm{NO}_{2}\right)_{2}$ chromophore. Lappin and Clark have shown for

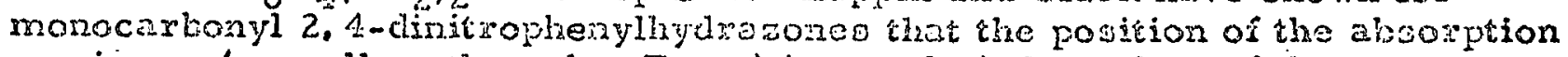

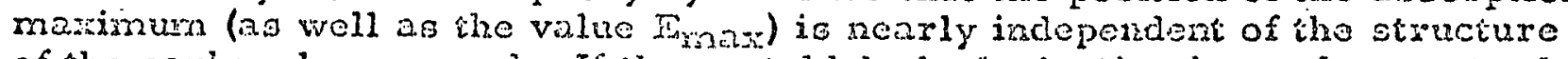
of the carbonyl compound. If the ecetaldohydo derivativo ia used as a stundard, an initial yiold of 1.2 carbonyl groups is obtrined fer 100 ev absorbed in the pepoin bolution. Pepsin in unitradiated controls blowed noglizible revention of 2,4-dinitrophenylhydzarize. Unizradiated gelatin solutions, on the othor hend, alvays ohowed a granll retenation.

To eliminate various uscertaintics involved in the above determination, a method was developed to measure $G(>C=0)$ directly in terme of $-G(2,4$ dinitrophonylhydrazizel. The protein solutions vere treated vith 2 , 4 -dinitrophenylhydrazine-hydrochlorit ach, and after reaction was complete, any excess reagent was renoved for aboay by successive extractions vith eqial volumes of ether. Tho timo roquirod for stoichiometric rouction vas determinod in separate hinetic studie日. Figure 8 shows the oftical densicies (in methanol-poinsium laydroxidel of control and ixwadiated gelatin solutions as a funciton of tire initial concentsation of 2,4 -dinis rophenylinydrazine. The data of Fig. 8 give $-G(2,4$-dinitropheny?hydrazine $\}=1.5$. This volue is 
essentially the same as that obtained by the mothod in which acetaldehydo 2. 4-dinitrophenylhydzazone le used as a reference standard. Figuro 8 also ahowg that there is oome interaction between unirradiated protein and 2. 4-dinitrophenylhydrazine reagent.

Part of the carbonyl function measured by the above techniques has been found to be asoociated with a-keto acida liberated on hydrolygio of the frradiated and dialyzed protein. In these atudies tho ixradiated protein solutiono were hydrolyzed in $4 \mathrm{~N} \mathrm{HCl}$ (in vacuo) for 24 hour o prior to treatment with 2. 4-dinitrophenylhydrazine reagent. (We found it neceosary to add the hydrazine reagent after hydrolysis, oince hydrazone derivatives are genorally rather rapidly destroyed by hearing in mineral acide.) The hydrazone derivativon woro oxtraotod with ohloroform and oraminod ohromatographical" 1y. 18 It vas found that the irradiated oanples yield a serieg of a-leto acido. The relative yields of the se products roughly reflect the amino acid composition of the initial protein. It lo of interest to note also that control runs vith unirradiated pepsin showed the presence of measurable amounto of pyruvic acid. This apparently arisea from the decomposition of oerine during acid hydrolyots. Pyruvic actd was observed only in traco amount in gelatin hydrolyzated, presumably because of the lower serine content of the latter. Most of the keto acid identification studies vere therefore made on the irradiated gelatin oystem. The following keto acid products have been identified: oxaloacetic, a-ketoglutaric, glyoxylic, pyruvic, and phenylpyruvic. Identification was based on the fact that in each caso the 2.4 -dinitrophenylhydrazone derivative s could not be distinguiohed chromatographically from the correeponding authentic material. Typical chromatographs of the a-keto acid hydrazones recovered from an irradiated gelatin colution and an identical control solution are shovn in Fig. 9. As a second independent method of ideritification, each of the separated keto acid hydrazones was converied into the correoponding amino acid by catalytic hydrogenaticn. Chromatographic characterization of the amino acid in each case confirmed the original product identification. We also considered the posoibility that transmutation reactions may occur during hydrolyois once a particular keto acid has been released. If ouch a reaction did occur it would, of course, introduce on unccrtainty in the identification of the initial carbonyl products. The results of a veries of control rung, however, vitiated this possibility. (See also reference 19). Carbonyl products in addition to those ascociated with the a-keto acid fraction have also been observed. Studies of thece other fractions aro in progress.

Substantiating evidence for the proposed radiation-induced oxidation of the poptide bond has also been obtained from tudies of the amide content of reaction products formed by $\gamma$-ray-induced oxidation of aqueous gelasin. 20 Commercially available lime-proceso gelatin was found to be particularly. ouitable for this study since most of the amido groups of the glutarnine and asparagine residues of the parent collagen are removed through hydrolyois during the manufacturing process. Unmodified proteins, in general, contain amide groups in sufficient number to mask the radiation-induced reaction at the-lover radiation dosages necessarily invoked in studies of initial rcaction products. Analyses wore made for "free" arnmonia and for amide groups. both before and after irradiation. Analytical methods esocrially were those developed by Vickery. The data indicate that the formation of amide groups $(G=1)$ correoponds to one of the principal reactions involved in the radiolysis of aqueous solutions of gelatin. The $G$ value for this product group is very 
close to that obtained for total carbonyl formation under equivalent irradiation conditions. Although the simplest explanation for thid correspondence would secm to involve the postulated raaction we cannot conclude at the present time that other undefined reactions do not contribute to the amide yield as measured. Ammonia formation $(G=0.3)$ may be attributed to a radiationInduced oxidation of terminal and (or) side-chain amino groups.

Thlo work was performed under the auspices of the United States Atomle Energy Commission.

\section{REFERENCES}

1. Dewhurst, H. A, and Burton, M. Radiolysle of Aqueous Solutions of Hydrazine, Jo Am, Chem, Soc. 77, 5781 (1955).

2. Hochanadel, C. J. and Lind, S. C. . Radiation Chemistry. Ann. Rev. Phys. Chem. 7. 83 (1956).

3. Dale, W. M. Davies, J. V. and Gilbert, C. W., The Klnetlcs and Specificities of Deamination of Nitrogenous Compounds by X-radiation; Brochem. J. 45,93 (1949).

4. Stoin, G. and Welos, J. . Chemical Actions of Ionlzing Radiations on Aqueous Solutions. Part IV. The Action of X-rays on Some Amino Acids, J. Chem. Soc. 1949, 3256.

5. Barron, E. S. G. . Ambrose, J., and Johnson, P. . Studies on the Mechanism of Action of Ioniaing Radiations. XIII. The Effect of XXirvadation on some Physico-chemical Properties of Arnino Acids and Proteins. Radiation Research 2. I45 (195's).

6. Maxwell, C. R., Peterson, D. C. , and Sharpleso, N. E.. The Effect of Ionizing Radiation on Amino Acids. I. The Effect of X-rayg on Agueous Solutions of Glycine, Radiation Research 1, 530 (1954).

7. Maxwell, C. R. , Peterson, D. C. , and White, W. C. . The Effect of Iontzing Radiation on Amino Acids. III. The Effect of Electron Irradiation on Aqueous Solutions of Glycine, Radiation Kesearch 2 , $431(1955)$.

8. Wecka, B. M. and Garrison, W. M. . Radiolysis of Aqueous Solutions of Glycine, Radiation Research 9, 291 (1953).

9. Moore, S., and Stein. W. H. , Chromatography of Amino Aclda on Sulfoneted Polystyrene Resins, J. Biol. Chem. 192, 663 (1951).

10. Marvel, C. S. and Randa, R. D. Jr. . Separation of Organic Acida, J. Am. Chem. Soc. 72, 2612 (1950).

11. Garrison, W. M. . Bennett, W. Cole, S. Haymond, H. R., Weeka,

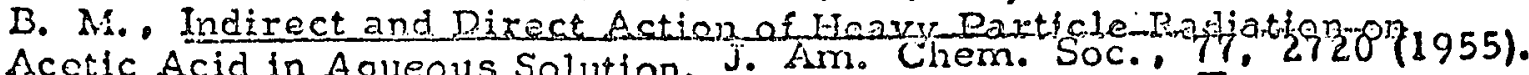


12. Weeks, B. M. and Garrion, W. M. Formatson of $C^{84}$-labeled Proteln Derivatives in the Radiolysis of Aqueous Pepsin-Cl4 3 COOH Soluilons, Radiation keseatsch 90202 (1958\%

13. Weeks, B. M.. Cole, S. a and Garrison, Wo M.o Radical-combination Reactions in the Radiolysis of Protein-CH${ }_{3} \mathrm{Cl} 40$ OH Solutiong. in Eiology and Medicine Semiannual keport。 UCRL-8705. April, 1959.

14. Jayko, M. E. . and Gaxrison, W. M. Indirect Action of Radiation on the - $\mathrm{NH}-\mathrm{CH}_{2}$ - Linkage in Diethylamine (A Mechanism for tho kadiationInduced Decomposition of the Peptide Chain). J. Chem. Phya.. 25. 1084 (1956).

15. Jayko, M. E. and Garrison, W. M. Formation of $>C=0$ Eonds in the Radiation-Induced Oxidarion of Proteln in Aquoous Systems. Nature, $13{ }_{0} 413(1950)$.

16. Jaylco, M. D. and Garrioon, W. M. . Dotermination of Carbonyl Product Formed in tho Radiolyois of protein aystems, in biology and Medicino Semiannual Report, UCRL-6705, April. 1959.

17. Lappin. G. R. and Clark. L. C. Colorimerric Method for Determination of Tracer of Carbonyl Compounds. Anal. Chem. 23, 541 (1951).

18. Cavallind, D. Frontall, N.. and Toschi, G. Determination of KetoAcids by Partition Chromatography on Filter-Papex, Nature, 163. 563 (1949).

19. Franck, B. and Knolce, J. o a-keto Acidg in Proteln Hydrolysates. Chem. Bor. 90, 2450 (1957).

20. Bennett, W. and Garrison, W. M. . Production of Amide Groups and Ammonta in the Radiolyois of Aqueous Solutiong of Protein Naluie. $183.689(1959)$.

21. Vickery, H. B. The Rate of Hydrolysis of Wheat Giladin, J. Biol. Chem. 53, 495 (1922). 


\section{LEGENDS FOR FIGURES}

Fig. 1. Typical elution curve of nitrogen-containing products formed in the helium-ion irradiation of $0.25 \mathrm{M}$ glycize solution containisg

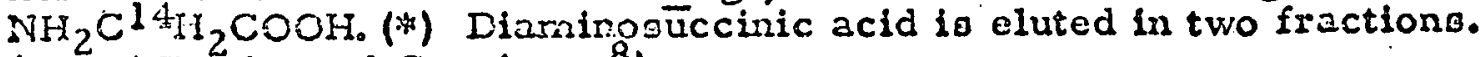
(From Weolo and Garrison. ${ }^{8}$ )

Fig. 2. Co-elution curves of authentic aspartic and diaminonuccinic acids with $C^{14}$-labeled product from $^{4}$ lycine. (From Woeks and Garrion. ${ }^{3}$ )

Fig. 3. Typical elution curve of $\mathrm{C}^{14}$-labeled compounds obtained from Irradiated gelatin- $\mathrm{CH}_{3} \mathrm{C}$ l $4 \mathrm{OOH}$ solukions after dialyolo and hydrolysio. (From Weeks, Cole, and Garrison. $13 j$

Fig. 4. Typical elution curve of $C^{14}$-labeled compounda obtained from Irradiated pepsin-CHI $3 \mathrm{C}^{14} \mathrm{OOH}$ oolutions after dialysis and hydrolyals. (From Wocks, Cole, and Garrison, UCRL-8265, April, 1958,)

Fig. 5. Typical elution curve of $C^{\$ 4}$-labeled compounds obtained from irradiated $\beta$-lactoglobulin-CHz ${ }_{3} C^{1 \Lambda}$ OOH oolutions after dialyeis and hydrolysio. (From Weelos, Cole, and Garrison. ${ }^{13}$ )

Fig. 6. Co-elution curve of authentic aspartic acid with $C^{14}$ activity froma pealk A of Fig. 4. (From Weeks, Cole, and Garrison, UCRL-8265, April, 1958.)

Fig. 7. Absorption spectra of hydrazone derivatives. (From Jayko and Garrison, UCRL-8265, April, 1953。)

Fig. 8. Effect of irradiation on the reaction of 2,4 -dinitrophenylhydrazine with gelatin. (From Jayko and Garrison. 16 )

Fig. 9. Chromatogram of 2, 4-dinitrophenylhydrazones of a-keto acids from control and irradiated gelatin solutions. (From Jayko and Garrioon. 16) 


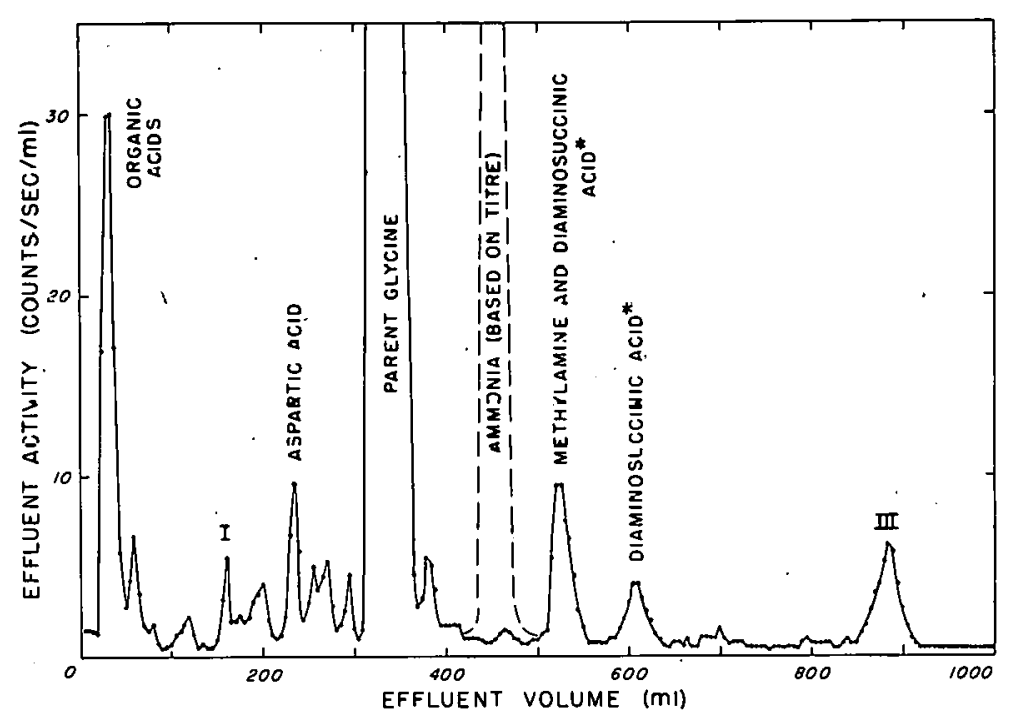

Fig. 1. 


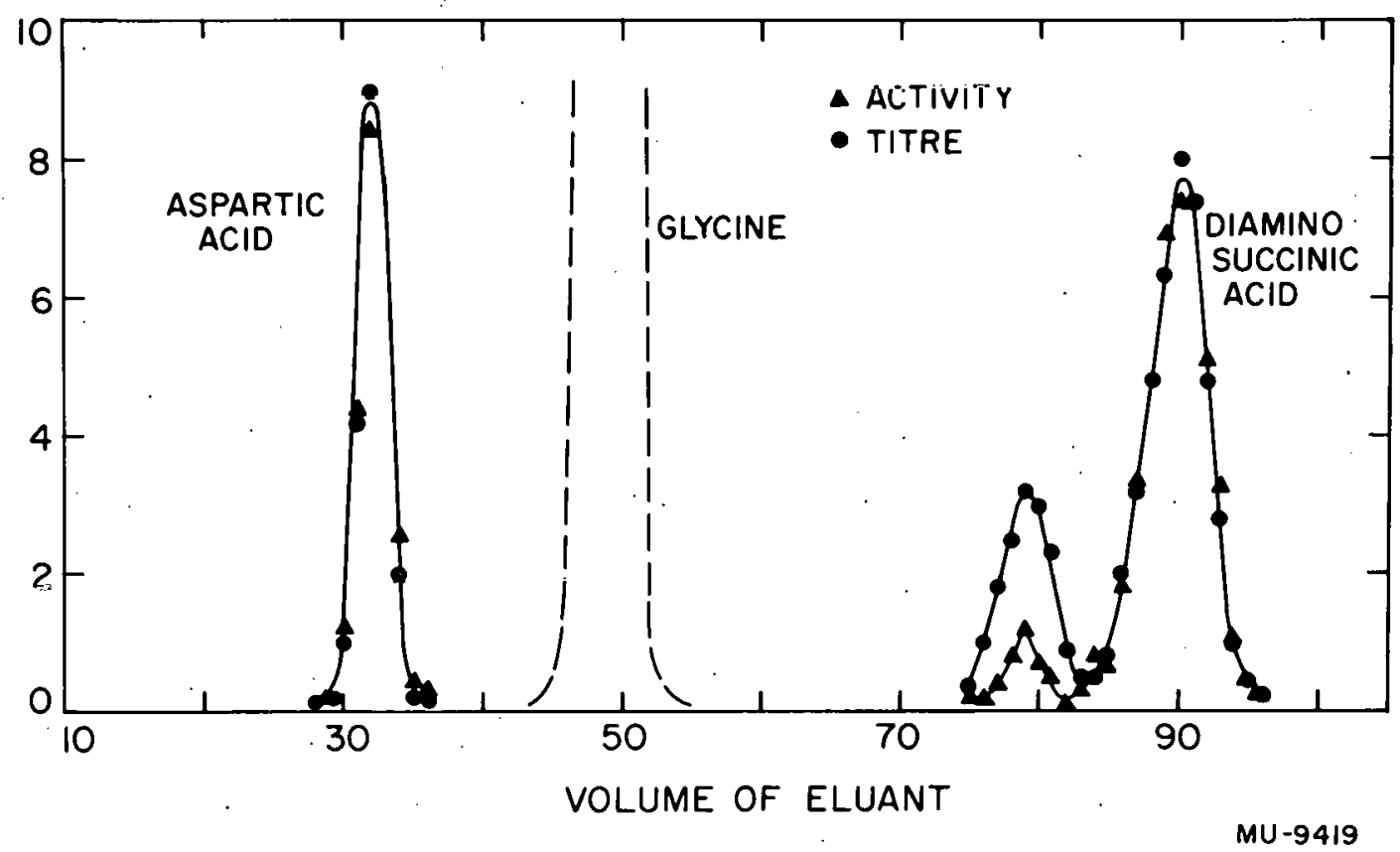

Fig. 2. 


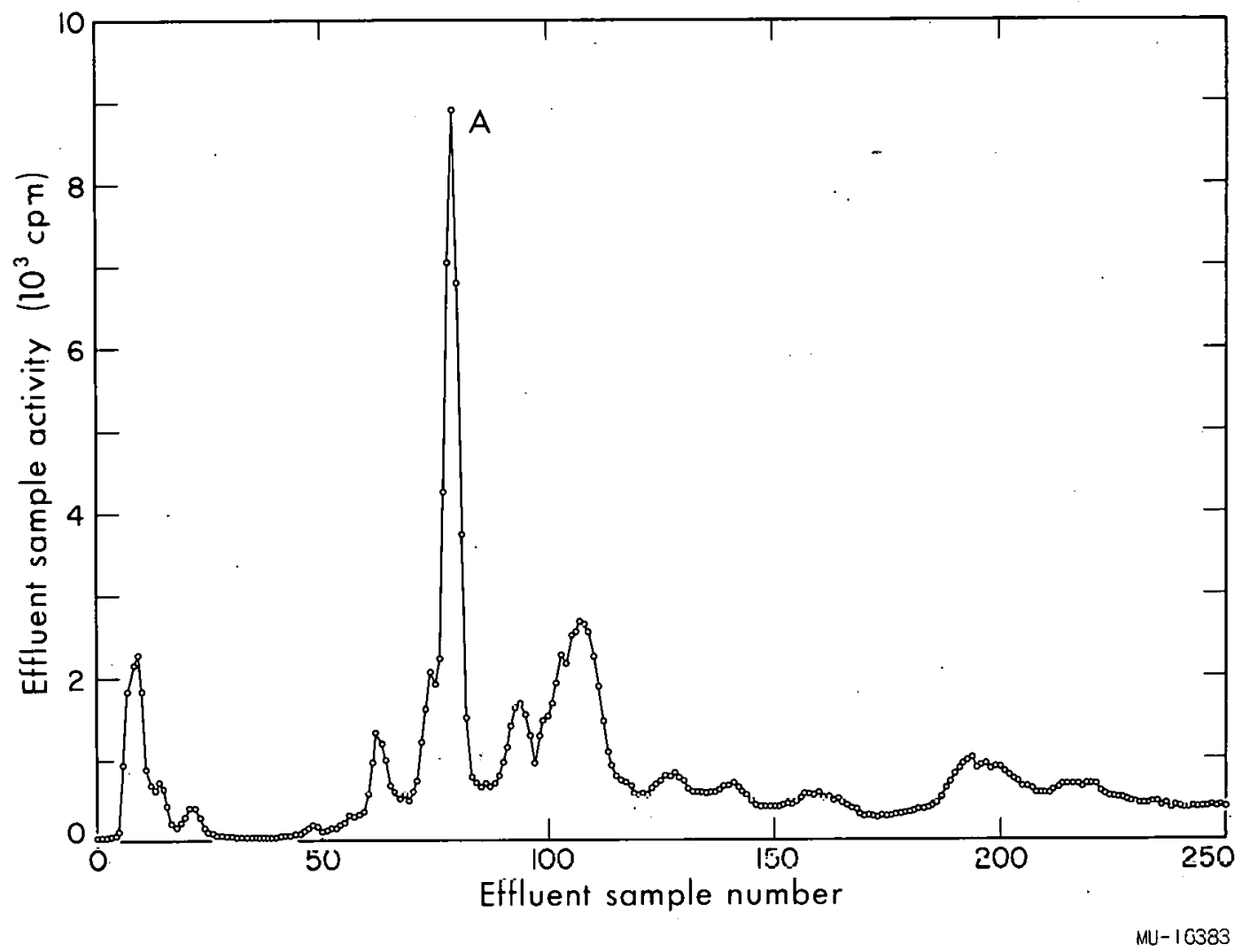

Fig. 3. 


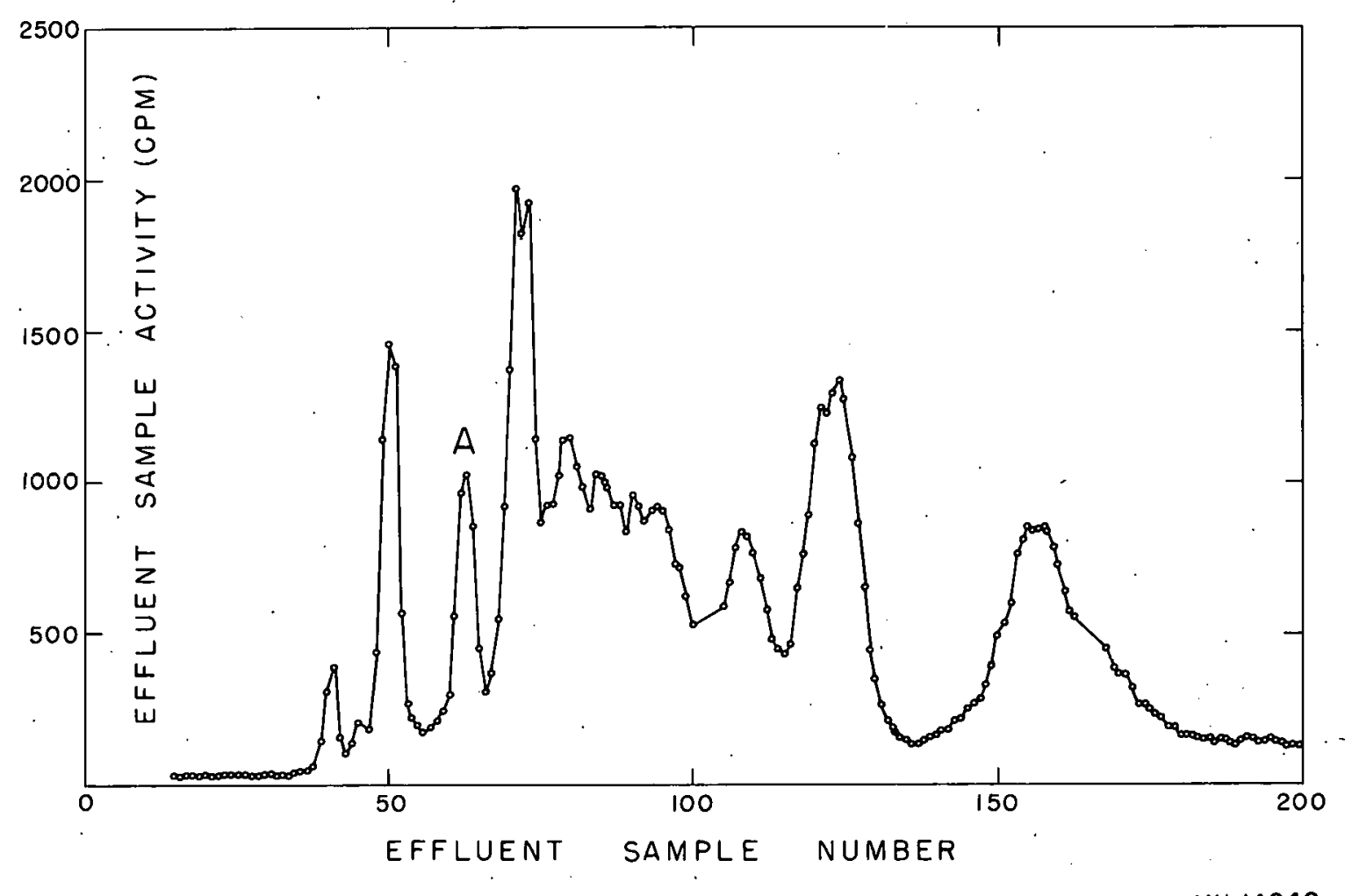

Fig. 4. 


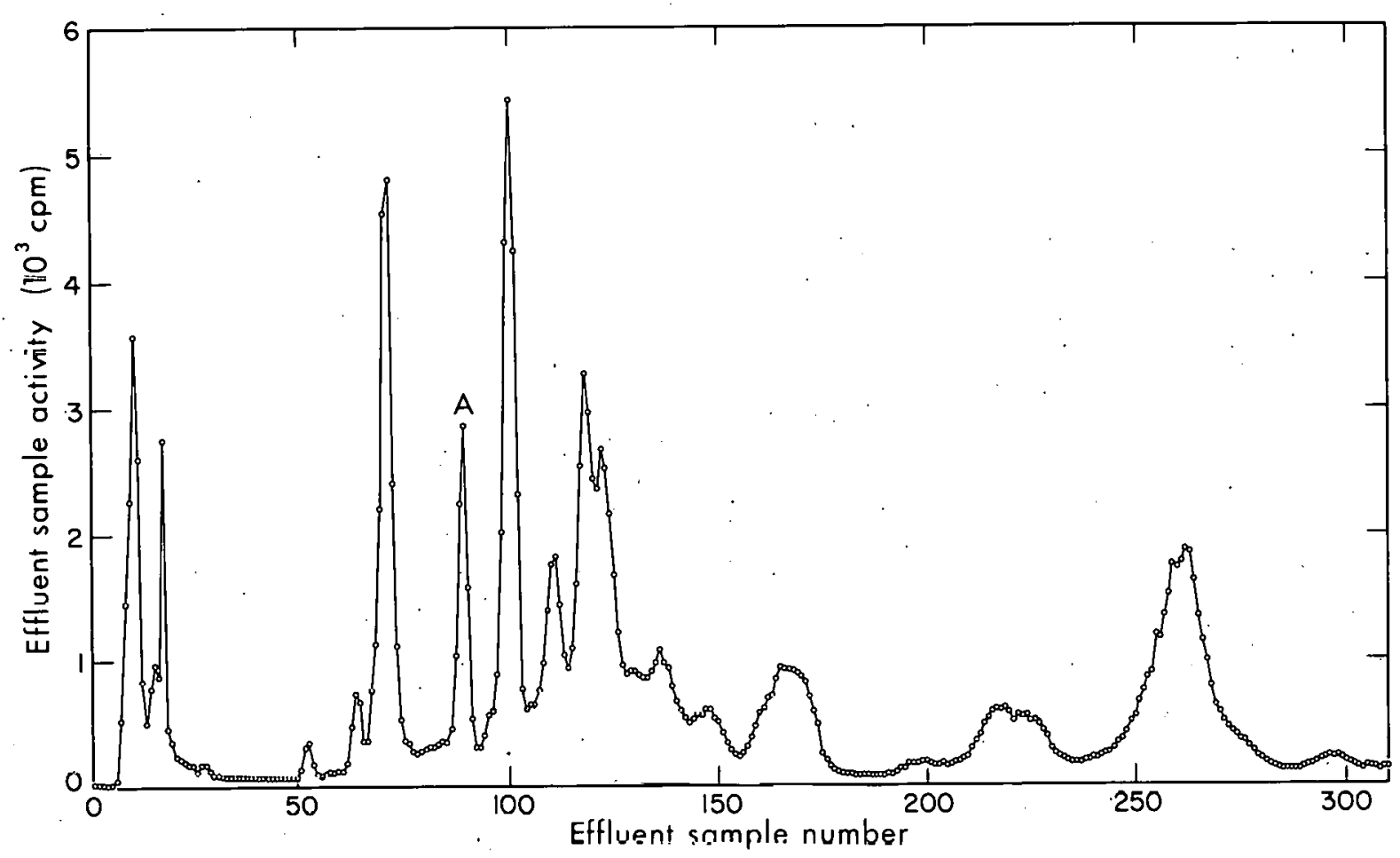

MU-16384

Fig. 5. 


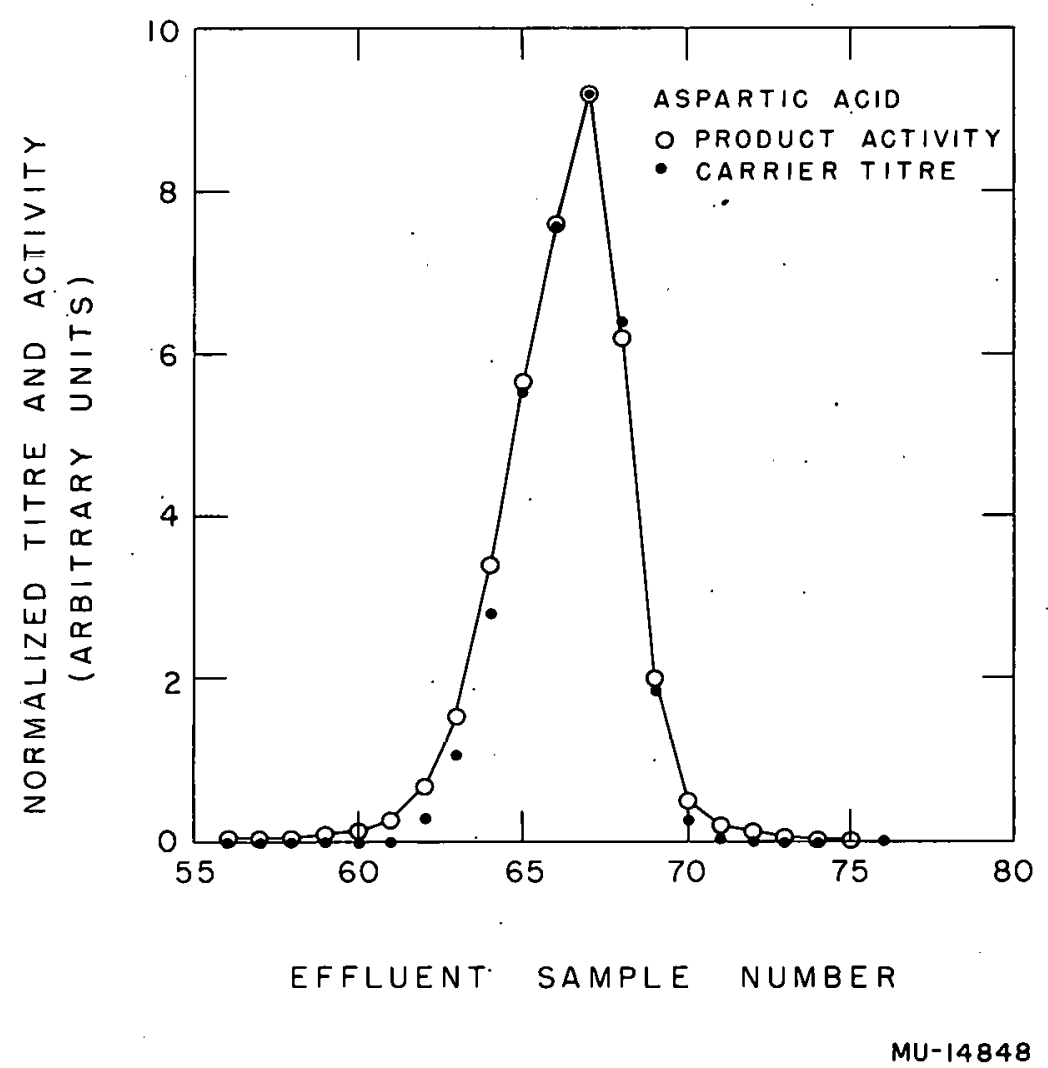

Fig. 6. 


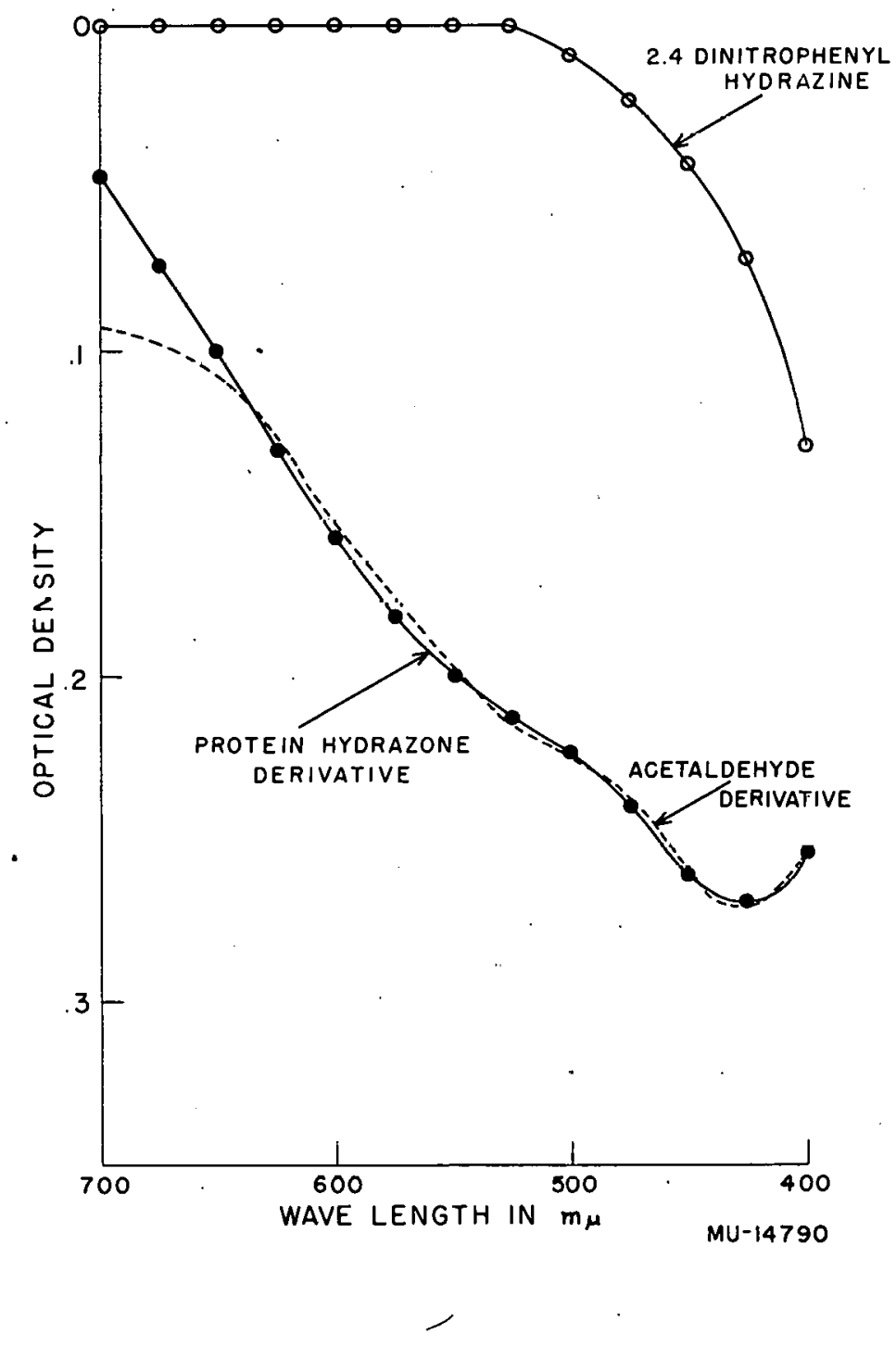

Fig. 7. 


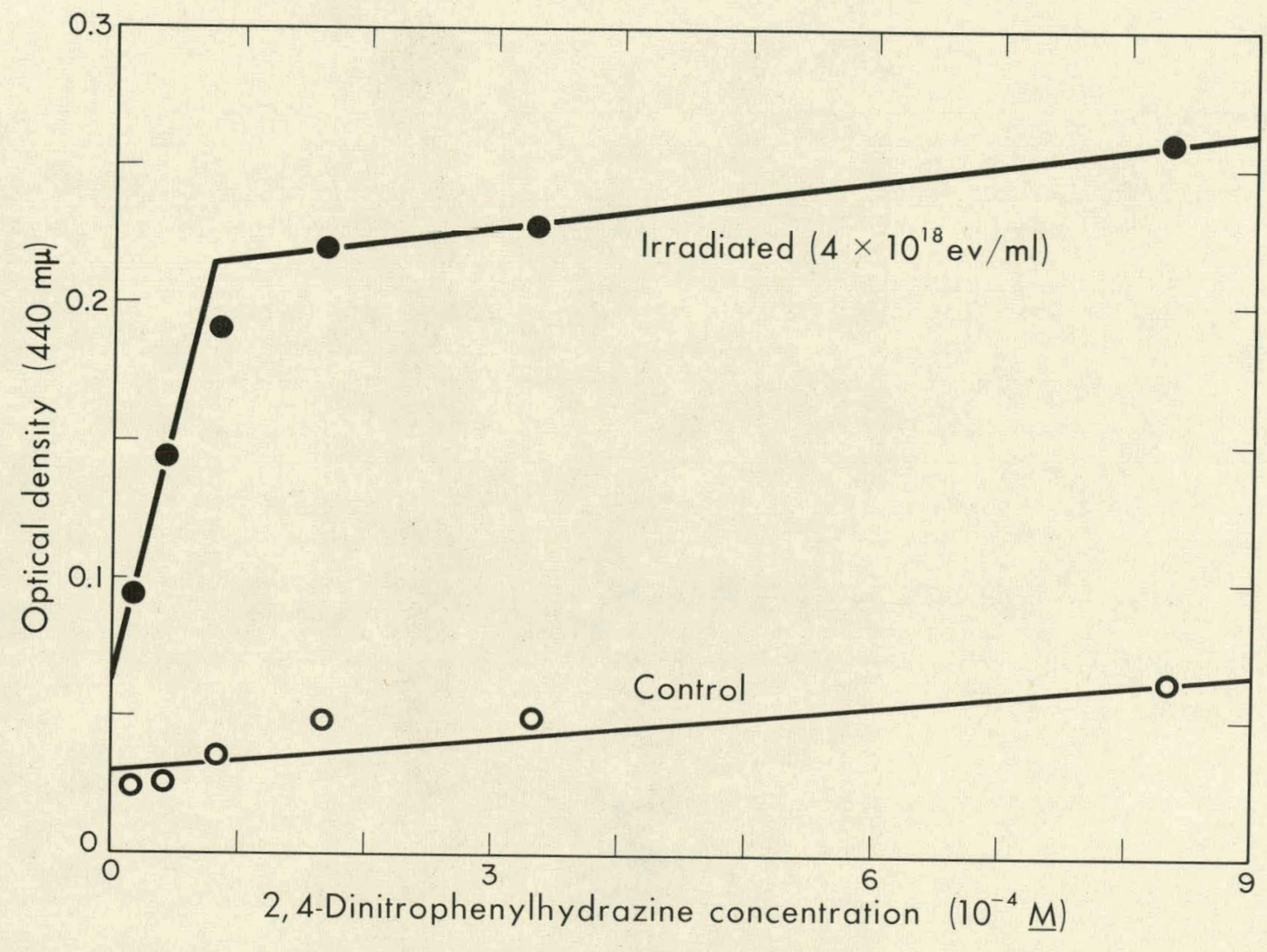

MU- 16382

Fig. 8. 
$-20-$

UCRL-8719

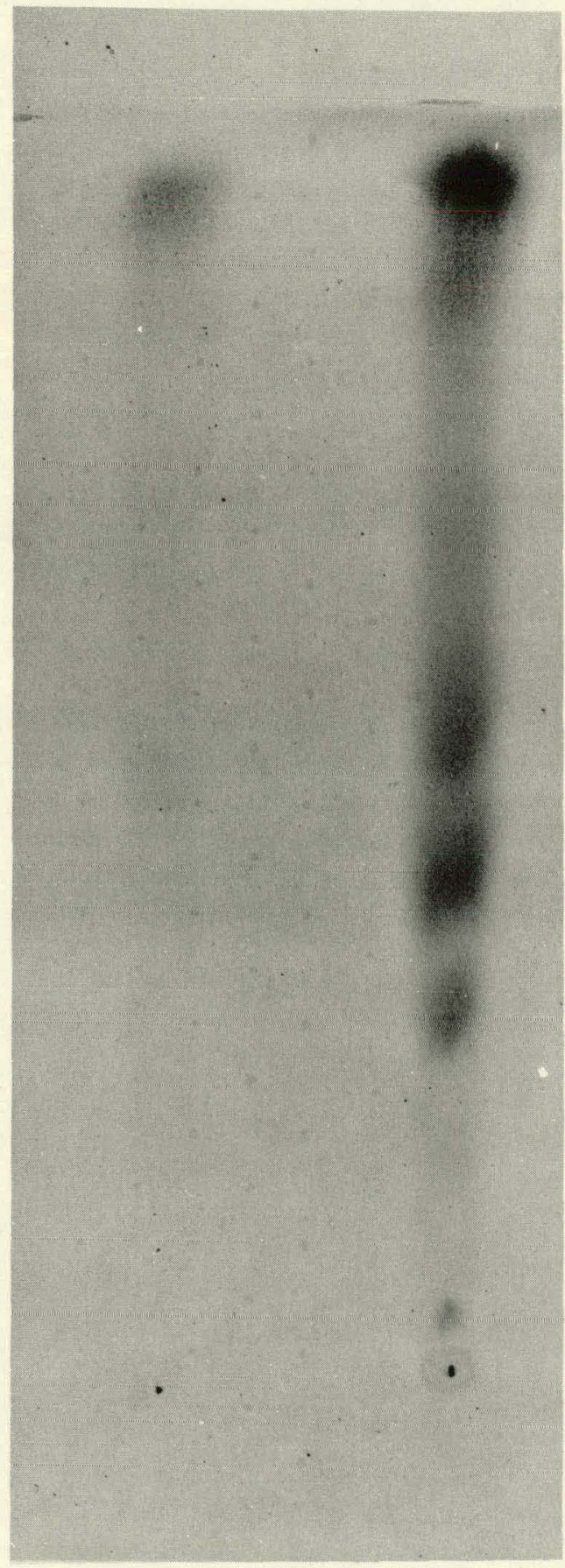

Fig. 9. 
This report was prepared as an account of Government sponsored work. Neither the United States, nor the Commission, nor any person acting on behalf of the Commission:

A. Makes any warranty or representation, expressed or implied, with respect to the accuracy, completeness, or usefulness of the information contained in this report, or that the use of any information, apparatus, method, or process disclosed in this report. may not infringe privately owned rights; or

B. Assumes any liabilities with respect to the use of, or for damages resulting from the use of any information, apparatus, method, or process disclosed in this report.

As used in the above, "person acting on behalf of the Commission" includes any employee or contractor of the Commission, or employee of such contractor, to the extent that such employee or contractor of the Commission, or employee of such contractor prepares, disseminates, or provides access to, any information pursuant to his employment or contract with the Commission, or his employment with such contractor. 